Abroze, E.A. (2020). Prevention of neurosis in parents of children with disabilities. European Scientific e-Journal, 6 (6), 1, 50-55. Hlučín-Bobrovníky: “Anisiia Tomanek” OSVČ.

Аброзе, Е.А. (2020). Профилактика неврозов у родителей Аетей с ограниченными возможностями зАоровья. European Scientific e-Journal, 6 (6), 1, 50-55. Hlučín-Bobrovníky: “Anisiia Tomanek” OSVČ.

$$
\text { DOI: } 10.47451 / \text { psy2020-09-001 }
$$

The paper will be published in Crossref, ICI Copernicus, Academic Resource Index ResearchBib, J-Gate, ISI International Scientific Indexing, Zenodo, OpenAIRE, BASE, LORY, LUASA, ADL, eLibrary, and WebArchive databases.

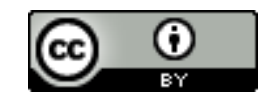

Eugeny A. Abroze, PhD Cultural Studies, Clinical Psychologist. St. Petersburg, Russia.

\title{
Prevention of neurosis in parents of children with disabilities
}

Abstract: According to statistics, for every 10,000 healthy children, there are more than 250 children with disabilities in developed countries. Official data of the World Health Organization confirms these figures. In the Russian Federation, 568,000 disabled children were registered in 2013, and by 2020 their number has increased to 688,000 . The author examines the main psychological problems of families with children with disabilities, as well as the therapeutic use of methods for preventing neurotic disorders in children. The article analyzes the possibilities of innovative types of neurosis prevention - with the help of psychohygiene and psychological cultural studies. The author concludes that disability and concomitant diseases are a powerful stressful factor that forms a complex of experiences, negative psychological deformities in both children and their parents. Deeply correlated psychological complexes actively influence the processes of therapeutic and rehabilitation activities of the child and the adaptation of the family negatively affecting the positive result in every possible way.

Keywords: prevention of neuroses, modern psychiatry, hygiene, psychological cultural studies.

Евгений Артурович Аброзе, кандиАат культурологии, клинический психолог.

Санкт-Петербург, Россия.

\section{Профилактика неврозов у родителей Аетей с ограниченными возможностями зАоровья}

Аннотачия: Согласно статистике, на каждые 10 тысяч здоровых детей в развитых странах приходится более 250 детей-инвалидов. Официальные Аанные Всемирной организации зАравоохранения (ВОЗ) подтвержАают эти цифры. В Российской Федерации в 2013 году было зарегистрировано 568 тысяч детей-инвалиАов, а к 2020 году их число увеличилось до 688 тысяч. Автор рассматривает основные психологические проблемы семей с Аетьми-инвалидами, а также терапевтическое применение методов профикактики невротических расстройств у детей. В статье анализируются возможности инновационных видов профилактики неврозов - с помощью психогигиены и психологических культурологических исследований. Автор приходит к выводу, что инвалидность и сопутствующие заболевания явцяются мощным стрессовым фактором, формирующим комплекс переживаний, негативных психологических деформаций как у детей, 
так и у их родителей. ГАубоко взаимосвязанные психологические комплексы активно вАияют на процессы мечебно-реабилитационной деятельности ребенка и аАаптации семьи, всячески отрицательно влияя на положительный результат.

Ключевые слова: профилактика неврозов, современная психиатрия, гигиена, психологическая культурология.

\section{Introduction}

According to statistics, for every 10,000 healthy children, there are more than 250 children with disabilities in developed countries. Official data of the World Health Organization confirms these figures (The number of disabled people in Russia and the size of the monthly cash payment, 2020).

In the Russian Federation, 568,000 disabled children were registered in 2013, and by 2020 their number has increased to 688,000. The upward trend is obvious (Shats, 2005).

Features of pathologies that caused disability and are defined by disability are directly related to both psychological and pedagogical problems in children and parents, problems that lead to difficulties in psychological adaptation, slowing down the process of socialization, and isolation of the family in society. We have to define the main psychological problems of families with children with disabilities.

1. Regret, sometimes carefully hidden or not realized but indirectly transmitted by parents, falls on the child's guilt. The internal conflict between reality and the desired becomes a difficult test for fathers and mothers.

2. Emotional deprivation of both the child and the parent can be formed if the parent spends their personal resources on the treatment and rehabilitation of the child, while mutual emotional contact either takes a back seat or is completely absent, so both the parent and the child fall into emotional isolation. They cannot express their feelings; they do not have the ability to be mutually acceptable and mutual.

3. The parent's awareness of the anxiety of the future, their child, getting used to the role of the patient, loss of faith in their strength, capabilities and abilities, is a serious psychotraumatic factor. As a consequence, the emergence of parental overprotection. As a result, low self-esteem, lack of responsibility for yourself, your own life. A disabled child gets used to the format of existence provided and protected by parents, which does not allow the son or daughter to express themselves.

4. The time factor and shortage of leisure activities. The parent does not have leisure time in their personal space. Therefore, it is not possible to 'reset' the accumulated fatigue and negative energy will be charged with cheerfulness and positive mood. This is only a small part of the psychological problems that lead to the formation of neuroses.

\section{The materials of the study}

Modern foreign psychiatry defines neuroses as psychogenic diseases, mostly caused by the influence of objective reality, expressed in various disorders of the mental, physical, and personal plan (Abroze et al., 2017). 
It must be recognized that for many years there has been a pathomorphism not only of neuroses as such but also of borderline neuropsychiatric and somatic diseases. In the leaders, neurotic forms with vegetative-visceral disorders, the number of erased, larvated forms of neuropsychiatric and somatic diseases, characterized by a prolonged chronic course and therapeutic resistance, is sharply increasing. In these conditions, disorders of neuro-dynamics by an organic process, secondary neuroticism, and the quality of the individual's response to the underlying disease become unavoidable companions of the pathological process (Ananyev, 2006).

The well-known truth that any disease is easier to prevent than to treat is also very relevant for neuroses. A comprehensive approach to the prevention of neurotic disorders, using multifaceted methods, gives a positive result. Conditionally, they can be divided into the following areas, based on the professor V.A. Ananyev's Concept of Health Potentials is a Comprehensive Program for Personal Development.

1. Emotional sphere. It implies the sensual, creative and spiritual side of the person, which can be realized through creativity in all its manifestations, through various creative spiritual practices, through participation in really socially significant projects.

2. The physical aspect of health. First of all, it means following the principles of a healthy lifestyle, a varied balanced diet, full sleep, sufficient physical activity, and the exclusion of alcoholic beverages and Smoking. Since physical activity plays a significant role in the regulation of homeostasis, it is necessary to discuss them in more detail. Active game sports, primarily team sports and martial arts were shown to be more effective in compensating for parental burnout.

However, the most important thing of all is to learn to get the maximum emotional pleasure, physical satisfaction from your actions, actions, and feelings, learn 'to catch' the harmony of your personality in all its manifestations and the objectively existing reality of the world around you.

The question often arises: 'Do I need to take a break from my disabled child?' The answer to this question cannot be unambiguous. It is no secret that the attitude of parents to their children is very different. There are examples of both completely irresponsible and unjustified overprotection. A small percentage of adequate parental interaction with the child is somewhere in the middle only. Of course, the disabilities give completely different diseases, but in any case, even if conditionally intact intellect, balanced approach to solving this problem is only correct when the parent not forgetting about their duties objectively assesses own capabilities, the needs of the child, the performance of leisure activities that can bring fatigue, and some related factors, individual to each case separately.

The psycho-hygiene is a special type of the prevention of neurosis. First of all, we are talking about regular visits to a psychotherapist (consultant psychologist). Observing the rule at least two times a year to visit the dentist, many people ignore the visit of another specialist, who is necessary for mental health. Psychological counselling is a form of psychological assistance that establishes a special kind of relationship and/or interaction between the consultant and the client (psychotherapist and patient), which allows you to cope with psychological difficulties, problematic situations, neutralizes the psychological component of psychosomatic disease, or blocks the further development of the disease (Abroze, 2010).

A new science - psychological cultural studies - opens up innovative methods in the prevention of neuroses and psychotherapeutic work. In the modern world, culture as a derivative 
of human mental activity becomes a multi-faceted, multi-aspect phenomenon based on its inherent branched internal structure and supporting a huge number of functions in society. Many elements of culture are characterized by special mobility in time, responsiveness and accuracy of transmission of features of the period, correlations with the mental processes of society (Abroze et al., 2016). All of them equips the specialist with the rich potential of world culture achievements, which significantly expands preventive methods of working with parents of disabled children.

\section{Conclusion}

Thus, disability and concomitant diseases are a powerful stressful factor that forms a complex of experiences, negative psychological deformities in both children and their parents. Deeply correlated psychological complexes actively influence the processes of therapeutic and rehabilitation activities of the child and the adaptation of the family negatively affecting the positive result in every possible way.

Therefore, only a systematic approach to the prevention of neurosis, which is working with the emotional and physical spheres of the individual, regular visits to a psychotherapist (psychologist-consultant) adapt the entire family to the living conditions associated with the child's disability.

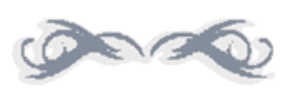

\section{References:}

Abroze, E.A. (2016). Psychological assistance to children with disabilities and their parents through integrative dynamic sand psychotherapy, psychological counseling and group dynamic non-contact body-oriented psychotherapy. LV International Scientific and Practical Conference "Problems of Pedagogy and Psychology". St Petersburg, Internauka. (in Russian)

Abroze, E.A., Buychik, A.G., \& Lebedev, S.V. (2016). Psychological uturology as a new science. Questions of modern science, 11, 22-40. Moscow, Internauka. (in Russian)

Abrose, E.A., Ospanova, L.V., \& Kapov D.M. (Comps.) (2017). Collection of normative legal and methodological materials on the organization of leisure of children and youth and their rehabilitation in Saint-Petersburg. St Petersburg: COO Youth. (in Russian)

Ananyev, V.A. (2006). Fundamentals of health psychology. Book 1. Conceptual foundations of health psychology. St. Petersburg, Rech. (in Russian)

Karvasarsky, B.D. (Ed.) (2002). Clinical psychology. St Petersburg: Peter. (in Russian)

Heuft, G. (2000). Lebrbuch der Gerontopsychosomatik und Alterspsychotherapie. München, Basel: E. Reinhardt. (in German)

Shats, I.K. (2005). Modern medical and psychological problems in children's oncology and some ways to solve them. Social and Psychological Aspects of Assistance with Oncological Diseases and Their Families, 32-46. St Petersburg. (in Russian)

The number of disabled people in Russia and the size of the monthly cash payment. 2020. Retrieved August 15, 2020 from https://rosinfostat.ru/invalidy/ (in Russian) 
World report on disability 2011. WHO Library Cataloguing-in-Publication Data. 2020. Retrieved August 19, 2020 from https://www.who.int/disabilities/world_report/2011/report/ru/ 